\title{
РЕАЛІЗАЦІЯ РЕГУЛЯТИВНИХ КОМУНІКАТИВНИХ ТАКТИК У СИТУАЦІЯХ НЕОПОСЕРЕДКОВАНОЇ ТОРГІВЛІ
}

\author{
ІРИНА ШКЦЦЬКА \\ Тернопільський національний економічний університет, Тернопіль - Україна \\ i.shkitska@gmail.com; ORCID: 0000-0002-0252-8111
REALIZACJA KOMUNIKACYJNYCH TAKTYK REGULACYJNYCH W SYTUACJACH HANDLU BEZPOŚREDNIEGO \\ IRYNA SZKICKA \\ Narodowy Uniwersytet Ekonomiczny w Tarnopolu, Tarnopol — Ukraina \\ i.shkitska@gmail.com
}

STRESZCZENIE. W artykule zostały opisane przejawy zachowań komunikacyjnych Ukraińców w sytuacjach handlu bezpośredniego. Wyodrębniono konstruktywne i destrukcyjne regulacyjne taktyki komunikacji, stosowane przez sprzedawców i kupujących, dokonano ich analizy. Omówione zostały sposoby komunikacji i środki językowe, mające wyraźny potencjał manipulacyjny.

Słowa kluczowe: komunikacyjna taktyka regulacyjna, taktyka konstruktywna / destrukcyjna, sposób komunikacji, środek językowy.

\section{REALIZATION OF REGULATIVE COMMUNICATIVE TACTICS IN DIRECT TRADE SITUATIONS}

\author{
IRYNA SHKITSKA \\ Ternopil National Economic University, Ternopil — Ukraine \\ i.shkitska@gmail.com
}

ABSTRACT. The article focuses on the research of the communicative behavior manifestations of the Ukrainians in the direct trade situations. The constructive and destructive regulative communicative tactics used by sellers and buyers have been separated and classified. The communicative methods and linguistic means with the analyzed manipulative potential have been described.

Key words: regulative communicative tactics, constructive / destructive tactics, communicative method, linguistic means.

$\mathrm{H}$ априкінці XX - на поч. XXI ст. вивчення проявів комунікативної поведінки індивідів і різних соціальних груп набули особливої актуальності. Спостерігаємо збільшення кількості наукових розвідок з антропологічної лінгвістики та прагмалінгвістики, посилення інтересу й уваги мовознавців до міжкультурної комунікації та мовного вияву національної самобутності.

Різні аспекти використання мовних засобів відповідно до мети спілкування привертали увагу Ф. Бацевича, В. Зірки, О. Дмитрук, Т. Ковалевської, О. Іссерс, Л. Нефедової, Л. Балахонської, Ю. Баскової, Л. Веретенкіної, О. Денисюк, О. Галапчук та ін. Усе більше наукових розробок присвячено виокремленню 
й аналізу комунікативних стратегій, використовуваних у різних ситуаціях спілкування. Оскільки у сфері торгівлі відбувається велика кількість маніпуляцій, вивчення комунікативних тактик, застосовуваних учасниками торгівлі, становить чималий науковий інтерес.

Мета цієї статті - виявити та схарактеризувати регулятивні комунікативні тактики, що їх використовують українці як учасники неопосередкованої торгівлі.

Об'єкт дослідження - вибрані з усного мовлення і творів художньої української літератури мовні одиниці, тобто засоби реалізації регулятивних комунікативних тактик, характерних для ситуацій торгівлі. Предмет - особливості вербалізації регулятивних комунікативних тактик, використовуваних продавцями й покупцями.

Спілкування під час неопосередкованої торгівлі - один з видів ділової комунікації, для якої характерні визначеність ії метою та значущість висловлювань співрозмовників. Ці особливості реалізуються в шанобливому ставленні до комунікативного партнера, демонструванні поваги й симпатії до нього. Від інших ситуацій ділової інтеракції ситуації, характерні для торгівлі, відрізняє комунікативна поведінка продавця, що визначається підвищеною активністю: він показує більшу зацікавленість у налагодженні конструктивного діалогу, ніж потенційний покупець, прагне встановити дружні стосунки з партнером.

За результатом і перебігом спілкування комунікативні тактики умовно поділяють на конструктивні, нейтральні та деструктивні. Конструктивні тактики (тактики позитиву) спрямовані на гармонізацію спілкування; нейтральні - передбачають обмін інформацією і характеризуються емоційною нейтральністю; деструктивні - відзначаються непродуктивністю, призводять до виникнення комунікативних невдач, непорозуміння й припинення інтеракції.

За ступенем активності мовця серед комунікативних тактик розрізняють ініціативні (активні) та респонсивні. До використання перших мовець удається за своєю ініціативою, респонсивні тактики - це реакція на комунікативну поведінку партнера чи саму ситуацію спілкування.

Розглянемо регулятивні комунікативні тактики, застосовувані продавцями та їхніми клієнтами в ситуаціях неопосередкованої торгівлі. Такі тактики переважно спрямовані на гармонізацію стосунків зі співрозмовником. Загалом сьогодні в українській культурі спостерігаємо домінування маніпулятивних тактик позитиву у зв'язку з комерціалізацією різних сфер життя та високою конкуренцією у сфері торгівлі. Продавці намагаються бути ввічливими 3 потенційними покупцями й будувати стратегію спілкування так, щоб ділові відносини з ними були довгостроковими.

У ситуаціях торгівлі активно застосовуваною продавцями конструктивною тактикою вважають тактику підвищення значимості співрозмовника. Ї̈̈ суть полягає в повідомленні партнеру позитивної інформації про нього у вигляді компліменту, похвали чи схвалення або у вираженні позитивного ставлення до нього (див. про це $\left.{ }^{1}\right)$.

Як відзначав Ч. Стивенсон, „головне призначення ціннісних суджень - не повідомляти факти, а впливати"'. Цей учений розрізняв дескриптивний і дина-

1 I. Ю.Шкіцька, Маніпулятивні тактики позитиву: лінгвістичний аспект, Київ 2012, с. 60-146.

2 Ч. С тивенсон, Некоторые прагматические аспекты значения, [в:] „Новое в зарубежной лингвистике”, сб. науч. тр., гл. ред. Е. В. Падучева, Москва 1985, вып. XVI, с. 129. 
мічний способи використання мови. Суть першого способу полягає у фіксуванні, з'ясуванні та повідомленні своїх поглядів. Другий спосіб передбачає виявлення почуттів, моделювання настрою та переконань інших, а також спонукання до прийняття рішень і дій. Похвала, що містить оцінку, призначена викликати в адресата емоції, увести його в певний психологічний стан

Тактика підвищення значимості співрозмовника реалізується у субтактиці позитивного оцінювання потенційного покупця та в субтактиці вираження прихильності до нього. Типовим способом реалізування описуваної тактики є використання пестливих і позитивнооцінних форм звертань до потенційних покупців. Прояви такої комунікативної поведінки спостерігаємо в людей середнього, старшого та похилого віку, здебільшого щодо осіб жіночої статі: бабусю, таздинько (діал.), господинько, жіночко, зозулько, панунцю, панночко, хазяєчко (розм.); мої солодкі, мої хороші і т. д. Зауважимо, що форми звертань до осіб чоловічої статі, використовувані продавцями, відзначаються більшою стриманістю: пане, юначе; хлопиі.

У звертаннях продавців до покупців типовою $є$ генералізація - використання форми множини, зокрема дівчата / дівчатка, до однієї жінки чи дівчини або використання такого звертання, адресованого подружній парі, чи хлопцю й дівчині. Продавці чоловічої статі у звертаннях до потенційних покупців жіночої статі послуговуються позитивнооцінними звертаннями чи номінаціями на зразок: красуне, красунечко, гарні дівчата і под. Компліменти продавців, адресовані потенційним покупцям, стосуються їхньої зовнішності, віку та манери поведінки. Позитивне ставлення до покупця може бути завуальованим і містити натякидокори на зразок: Щось Вас давно не було [...], Щось Ви давно не заходили до нас.

Тактика підвищення значимості співрозмовника, використовувана продавцями, може бути не тільки ініціативною. Використання респонсивних компліментів спостерігаємо як реакцію на самоприниження покупця під час примірювання виробу або в контексті роздумів щодо використання пропонованого товару. Здебільшого негативна самооцінка покупця стосується зовнішнього вигляду та віку, напр.:

ПРОДАВЕЦЬ: А як Вам ия спідничка?

ПОКУПЕЦЬ: Пані, що Ви! Така коротка... Та я застара для неї!

ПРОДАВЕЦЬ: Пані, що Ви таке говорите! Ви старі??? Ви не бачили, у чому старі зараз ходять! (з усного мовлення);

ПОКУПЕЦЬ: Щось я така груба у иій сукні! Для неї треба худішої жінки!

ПРОДАВЕЦЬ: Пані, та у Вас ідеальна фігура! / Та Ви не бачили ще грубих! / Та що Ви таке говорите про себе! Вам нічого не бракує! (з усного мовлення).

Поширеною в ситуаціях торгівлі є тактика позитивного самопозиціонування продавця. У ній можна виокремити субтактики двох типів - самовихваляння та розхвалювання пропонованого товару.

Під час реалізування субтактики першого типу продавець позитивно оцінює передусім свої моральні якості (чесність, порядність, надійність, постійність), напр.: Мені чужсого не треба; Повірте, я на Вас нічого не заробляю; Я Вас не обманюю; Я Вам не брешу; Я тут кожний день (на роботі) / постійно, день у день стою; Та я від Вас нікуди не тікаю (з усного мовлення). У таких повідомленнях вплив на покупця щодо придбання ним товару посилюється запевненням в щирості дій продавця: Повірте; Чесно; Чесне слово; Навіщо мені Вам брехати?; Нащо я би брехав(ла) Вам? і под.

\footnotetext{
${ }^{3}$ Там же, c. $153-154$.
} 
Функцію позитивного самопозиціонування виконують також і повідомлення про великий досвід роботи, наявність кола постійних клієнтів, глибоку обізнаність 3 асортиментом та якістю пропонованого товару, уміння безпомилково визначати потреби потенційного покупця й успішно їх задовольнити (Я mym не один рік праuүюю; Мене тут усі знають і т. д.), напр.: (продавець на базарі зазиває покупців):

- Ось іще один вєс [...]. Беріть, бо скоро не стане [...]. Дядька Василя mym усі знають - у чергу стають.

- Та важко ж буде нести! - [боронилася жінка.]

- Зате їстиметься легко! ${ }^{4}$

Непрямою формою репрезентування описуваної тактики є поради не купувати певні види реалізовуваного товару (ідеться про товари невисокої якості, залежані чи прострочені), а також не купувати товар, що, на думку продавця, не личить потенційному покупцю, напр.: Знімайте, це не Ваше!; Oй, ия сукня Вас так старить!; Це не Ваш стиль!; Щось не те!; Ви зливаєтеся із иим кольором!; Ви така бліда в изьому!; Ого, воно так обліпило Вас!; Ви втопилися в ньому! (з усного мовлення). У такий спосіб у покупця формується думка про продавця як про людину чесну, яка прагне насамперед догодити клієнтові, а не продати товар. Психолог Р. Чалдіні із цього приводу зауважує, що продавці, які нібито йдуть проти своїх інтересів, мають намір заслужити довіру, щоб пізніше використати свій позитивний образ експерта й порядної людини, рекомендувати дорожчий товар 5 чи перетворити потенційного покупця на постійного клієнта.

Непрямим способом реалізування тактики позитивного самопозиціонування продавця $\epsilon$ також повідомлення покупцю про можливість обміну чи повернення товару, якщо він не підійде, а також про можливість відкласти товар або розкласти виплату за нього на певний термін, напр.: Пані, як не підійде, принесете - ми Вам поміняємо; Беріть! У разі чого - повернете! (з усного мовлення).

Моделі та формули мовленнєвого етикету пов' язані не тільки з типами комунікативних ситуацій і формами ввічливого спілкування, а й визначаються етнопрагматичними відмінностями, що „свідчать про варіативність правил міжособистісного спілкування в культурах різних народів". Так, описуючи комунікативну поведінку французьких вуличних торговців, І. Зленко зауважує, що, оскільки заробіток останніх залежить від кількості проданого товару, вони “не соромляться обирати засоби для досягнення своїх цілей”: можуть іти за покупцем, на ходу розхвалюючи свій товар, прагнуть розсмішити його в будь-який спосіб, не нехтуючи навіть легким фліртом ${ }^{7}$ Зазначене стосується також і поведінки українських продавців.

Однією з виражених рис національного характеру українців є кардіоцентризм - надмірна емоційність ${ }^{8}$. Під час торгівлі емоційність українців про-

${ }^{4}$ А. Дім аров в Сільські історії, Київ 1987, с. 180.

${ }_{5}^{5}$ Р. Чалдин и, Психология влияния, Санкт-Петербург 2002, с. 217-218.

6 P. Р. Таджибова, Коммуникативно-прагматические особенности речевого этикета в различных лингвокультурах (на материале английского и лезгинского языков), [в:] „Вопросы когнитивной лингвистики”, 2013, вып. 2 (035), с. 151.

${ }^{7}$ И. П. З З ен ко, Коммуникативное поведение франиузского продавиа, [в:] ,,Русское и франиузское коммуникативное поведение”, сб. науч. тр., научн. ред.: И. А Стернин, Р. А. Ермакова, Воронеж 2002, вып. 1, с. 19.

${ }^{8}$ T. А. Кос ме да, Ego i Alter Ego Tapaca Шевченка в комунікативному простоpi щоденникового дискурсу, Дрогобич 2012, с. 51; В . С ліп ецька, Засоби вираження негативних емочій під час сварки в українській, російській й англійській лінгвокульmурах (на матеріалі творів I. Нечуя-Левицького, М. Гоголя, Ч. Діккенса), [w:] „Studia Ukrainica Posnaniensia", 2018, Vol. VI, c. 161. 
являється в жартах. Їх можна розглядати як прояв тактики позитивного самопозиціонування. Чимало жартів вуличних торговців-українців стали усталеними висловами (напр., Без грошей тільки мухи женяться. Проба грошей не коштує) або модифікованими фразеологізмами (напр., Краще один раз скуштувати, ніж сто разів почути!).

Характерно, що продавці вдаються до жартування на різних етапах торгівлі, порівн.:

1) відповідь на запит інформації, напр.:

ПОКУПЕЦЬ: А у Вас м'ясо свіже?

ПРОДАВЕЦЬ: Учора тільки хрюкало! (з усного мовлення);

ПОКУПЕЦЬ: А скільки коштує Ваше сало?

ПРОДАВЕЦЬ: Мос сало, пані, при мені, а свиняче - по 100! (з усного мовлення);

ПРОДАВЕЦЬ: А можна вибрати грушки?

ПОКУПЕЦЬ: Вибирайте, котрі на Вас дивляться! (з усного мовлення);

2) зазивання, з'ясування намірів співрозмовника, напр.: Дівчатка, ви прийшли щось вибирати чи витрішки продавати?; Пані, візьміть мене із собою! (з усного мовлення);

3) етап торгування, вихід із контакту, напр.:

ПОКУПЕЦЬ: Пане, а продасте нам трохи дешевще?

ПРОДАВЕЦЬ: Таким гарним дівчатам чого ні? (з усного мовлення).

Доволі поширеним способом створення жартівливої тональності в ситуаціях торгівлі $є$ персоніфікування товару: Ця сумочка на Вас чекала!; Дочекалася таки Вас ия спідничка!; Мала таки бути Ваша!; Це не я, ие суконка до Вас загукала: Пані, пані, купіть мене!; А, бачте, як очя сукня Вас заманила: Купіть мене, naнi!. Засобами створення жартівливої тональності часто постають діалектизми, пестливі форми слів, оксюморон, рима, напр.: (продавець морозива зазиває покупців в електричці) Львівське чоколядове (діал. - шоколадне) морозиво, тверденьке, смачненьке, щойно з п'єца! (діал. - пічки); Пані, станьте! Купіть чоловікові шкарпєта (діал. - шкарпетки) (з усного мовлення).

Слід зауважити, що невдалі жарти можуть призводити до комунікативної невдачі та руйнувати встановлені ділові зв'язки. Здебільшого це трапляється в ситуаціях, коли жарт, неправильно витлумачений покупцем, або межує з іронією, або сарказмом, напр.:

ПОКУПЕЦЬ: Пані, дайте мені иукерок иього виду по 100 г.

ПРОДАВЕЦЬ: Може, Вам ще по 50 г зважити?

ПОКУПЕЦЬ: Може! Але куплю я їх в іншого продавия. У Вас купувати нічого не буду (з усного мовлення).

Іншою субтактикою тактики позитивного самопозиціонування, використовуваної продавцями, є рекламування товару, напр.:

- Ну що, таздинько, берете миску? - [питає веселовусий жсартівник недовірливу молодищю.]

- Щось Ви дорого тягнете, вуйку.

- Така миска і дорого?! - [здивовано округлює очища вусань] - Люба моя, покладьте ї̈ на стіл порожньою перед дітьми, наситяться тільки тим, що увидять таке красне квіття й пташки на денці, а увечері повісьте на стіну-замість ліхтаря миска вам світитиме ${ }^{9}$. c. 47 .

${ }^{9}$ Д. Кешеля, Осінь великих небес, або прирічанські характери, Ужгород 2006, 
Тактика позитивного самопозиціонування може бути ініціативною та респонсивною. У тактиці першого типу продавець постає ініціатором самовихваляння. Тактика другого типу є реакцією на запитання чи інтерес співрозмовника до товару або особи продавця. Оскільки в ситуаціях торгівлі продавець часто асоціюється з товаром, який він продає, тактика позитивного самопозиціонування частіше передбачає вихваляння реалізовуваного товару.

Типовим прийомом, до якого вдаються продавці під час рекламування товару, $\epsilon$ його протиставлення товарам конкурентів або загалом продукції низької якості, напр.: Це не дермантин, що там продається!; Хочете, щоб розлізлося завтра, купуйте на базарі!; Я китайським ганчір'ям не торгую! (з усного мовлення).

Під час реалізування субтактики вихваляння товару продавці часто використовують маніпулятивний принцип соціального доказу, що полягає в повідомленні інформації про затребуваність товару та його популярність серед споживачів ${ }^{10}$ : До нас навіть кияни приїжджають скуплятися; Та я ию ковбасу постійно за кордон передаю; Мої постійні клієнти беруть тільки це; Хто спробував мій товар, купує тільки у мене / шукає тільки мене, іншого не схоче; У мене півміста одягається і т. д. На відміну від принципу соціального доказу, принцип авторитету ${ }^{11}$ значно рідше застосовується в ситуаціях торгівлі. Передумовою використання останнього $є$ наявність авторитетних клієнтів у продавця або спільних із покупцем впливових знайомих.

Для комунікативної тактики позитивного самопрезентування більшою мірою, ніж для інших регулятивних тактик, характерний прийом перебільшення, що реалізується за допомогою риторичних запитань, використання гіпербол, емоційно забарвленої лексики, підсилювальних слів тільки, лище, та і под., напр.: Та ие не сир - диво / казка!; Це не диня - мед!; Халва - пальчики оближеш! (розм.) (з усного мовлення).

Зазивання та вихваляння товару продавцем можна розглядати в межах тактики привернення уваги, виявом якої вважаємо і запит інформації. Нейтральними формами реалізування цієї тактики є запитання на зразок: Може, Вам потрібна моя допомога?; Вам чимось допомогти?; Вам щось підказати?; Вам допомогти? Менш увічливими є такі форми: Що Ви шукаєте?; Ви щось хотіли?; Ви щось шукаєте?; Вам щось потрібно?

Низький конфліктогенний потенціал мають запити інформації з відтінком неформальності (напр., Що то має бути?). Серед мовних конструкцій, що реалізують згадану комунікативну тактику, конфліктогенним потенціалом відзначаються запитання, що стосуються цінового діапазону продукції, яку хоче придбати потенційний покупець (напр., А на яку суму Ви розраховуєте?). У таких ситуаціях можливі негативні реакції у вигляді обурень, напр.: Не рахуйте мої гроші!; Що Ви рахуєте мої гроші!; Якщо мені щось сподобається, то куплю за будь-яку иіну! і т. д.

Однією з поширених комунікативних регулятивних тактик у ситуаціях торгівлі є тактика вмовляння. Реалізовуючи ії, продавець схиляє потенційного покупця до придбання того товару, який серед інших пропозицій він розглядав як найкращий. Маніпулятивним прийомом, використовуваним під час умовляння, $\epsilon$ запитання, що передбачає вибір із двох пропозицій, а не щодо здійснення покупки взагалі: То Вам давати ию помаду чи ту?, порівн. із запитанням То Bu будете щось купувати?.

\footnotetext{
${ }^{10} \mathrm{P}$. Чалдин и, указ. источ., с. 114-115.

${ }^{11}$ Там же, с. 200.
} 
Для тактики вмовляння характерне повторення прохань купити товар, супроводжуване формами ввічливості (будь ласка, дуже Вас прошу), а також використання прийому аргументування. Відзначимо, що продавці застосовують i раціональні аргументи, й аргументи, призначені впливати на емоції покупця. Раціональними вважаємо аргументи щодо оптимальної чи низької ціни на товар, а також щодо затребуваності його на споживчому ринку. Як найдієвіші аргументи, що спонукають до придбання товару, для більшості українських споживачів продавці використовують інформацію про низьку ціну товару (Пане, ие дешевще, ніж борщ!; Віддаю по закупиі, демевще не знайдете!; Та Ви подивіться тільки, яка ціна!; Пані, а Ви циіну бачили?! і под.), а також інформацію про високу якість продукції ( $Я$ за якість товару відповідаю!; Барахла не вожу!; Ви поносите цее!; Пані, Ви в иій курточиі до пенсії ходитимете!; Ця сукня швидше набридне Вам, ніж зноситься (з усного мовлення). Емоційні аргументи містять повідомлення про те, що товар підходить покупцю. Функцію емоційного впливу виконують також жарти, напр.: Ви не пожалкуєте; Будете носити й мене згадувати! (з усного мовлення).

Під час переконування покупці використовують психологічні слабкості потенційних покупців й апелюють не тільки до страху (утратити можливість вигідної / унікальної чи бажаної покупки й под.): популярним на українських ринках $\epsilon$ прийом активізування моральних якостей потенційного покупця, зокрема його співчуття: Виручіть мене, купіть!; Цілий день на ногах, а виторгу немає!; Купіть у мене останній кілограм сиру, і я поїду додому! і т. д. Зазвичай до таких прийомів маніпулювання вдаються непрофесіонали, продавці стихійного ринку - здебільшого люди похилого віку.

Серед маніпулятивних тактик позитивного впливу, використовуваних продавцями щодо потенційних покупців, виокремлюємо також тактику солідаризаціï. Ї̈і суть полягає в демонструванні спільного зі співрозмовником для здобуття симпатії, довіри та регулювання його поведінки ${ }^{12}$. У ситуаціях торгівлі ця тактика найчастіше виявляється в згоді продавця з потенційним клієнтом щодо оцінки товару, що викликав інтерес або не сподобався, напр.: I мені иі туфлі дуже подобаються; Мені теж ия сукня не до вподоби; Я собі ие теж постійно беру (з усного мовлення).

Способом неформалізування спілкування і своєрідним виявом тактики солідаризації є використання продавцями під час привернення уваги до себе і пропонованого товару дієслів у формі першої особи (Підходимо, вибираємо, куштуємо, порівн. Підходьте, вибирайте, куштуйте) та займенника ми замість ви, напр.: Дівчатка, а щзо ми шукаємо? (з усного мовлення).

Хоча використання деструктивних комунікативних тактик менш частотне, ніж нейтральних чи конструктивних, усе ж воно має місце в ситуаціях торгівлі. Деструктивні тактики вирізняе яскраво виражена респонсивність - зумовленість поведінкою співрозмовника. Так, негативні респонсивні реакції продавців найяскравіше виявляються у таких ситуаціях:

- коли потенційний покупець, передивившись чи перемірявши багато речей, далі виявляє незадоволення, не зупиняється на жодній пропозиції, нічого не купуючи;

- коли потенційний покупець негативно оцінює товар, цінову політику власника магазину або просто поводить себе некультурно чи виявляє недоброзичливе ставлення до продавця, напр.:

\footnotetext{
${ }^{12}$ I. Ю. Ш кіць ка , Маніпулятивні тактики позитиву..., с. 335-379.
} 
ПОКУПЕЦЬ: Щось ваш сир гіркуватий сьогодні!

ПРОДАВЕЦЬ: Пані, щуо Ви вигадуєте? (з усного мовлення).

Негативну реакцію продавців часто спостерігаємо на іронічний та емоційний коментар ціни і / або якості пропонованого товару. Ідеться про експресиви на зразок: Таке простеньке, а так дорого коштує!; Ну, й иіни ростуть - як на дріжджах!; Та воно не коштує стільки!; Ну, Ви і иіну лупите!; Що ж Ви так дерете?; Ого! Така изіна — як за рідного тата (рідну маму)!; Та йому гріш иіна в базарний день; Та воно ж у Вас залежане! (з усного мовлення). Іронічний ефект створюють і вигуки, і ненормативні номінації товару, напр., ужиті в неправильній родовій формі: Та ваші грушки ж гнилі! Куди ж його брати? (з усного мовлення).

Образливими для продавців є фрази клієнтів, адресовані своїм компаньйонам, напр.: Tym нічого немає!, що означає "У магазині немає потрібного / шуканого товару". Продавці здебільшого не реагують на такі твердження. Найтерплячіші з них намагаються з' ясувати, що шукає покупець, або запевнити відвідувачів у тому, що вибір пропонованого товару є доволі великим, напр.: Пане, та в нас великий вибір! (з усного мовлення).

Серед деструктивних комунікативних тактик, використовуваних продавцями, виокремлюємо такі:

- тактика докору, напр.: Я на Вас витратив стільки часу!; То Ви, перемірявии все, так нічого $i$ не купите? (з усного мовлення). Зауважимо, що тактика докору часто супроводжує тактику вмовляння;

- тактика негативного оцінювання співрозмовника, що полягає в несхваленні поведінки або рис характеру потенційного покупця (непослідовність, капризність, неввічливість тощо), а також у негативному оцінюванні його платоспроможності, напр.: Ви морочите мені голову!; Ви самі не знаєте, що хочете!; Вам не догодиш!; То Ви такі вибадливі!; Така молода, а така скандалістка!; Це не на Вашу кишеню!; Це товар не для Вас!; Ходять, самі не знають, шзо шукають / щзо хочуть! (з усного мовлення). Зауважимо, що негативна оцінка потенційного покупця часто має завуальований і непрямий характер. Це зумовлено самим характером соціальної ролі продавця;

- тактика залякування. Під час іiі реалізування продавці повідомляють інформацію про те, що ціни конкурентів на цей товар є вищими, про їх неуспіх, про обмежену кількість свого “унікального” товару тощо. Ця тактика часто має вигляд “відсилання” клієнтів — перевірити ціни, знайти аналог товару чи товар за такою самою ціною в конкурентів. В основі цієї тактики лежить принцип дефіциту: „цінність чогось позитивного в наших очах суттєво зростає, якщо воно стає недоступним"13. Описувану тактику репрезентують категоричні висловлювання на зразок Дешевше / Таньше (діал.) ніде не знайдете!; Пошукайте / шукайте дешевше, але дешевше, ніж у мене, не знайдете!; Спитайте иіну на початку ряду!; Ще до мене повернетесь!; Усе одно прийдете до мене!. Імпліцитний смисл таких повідомлень - самовихваляння: “Мій товар найкращий; Ціна на товар, який я продаю, — найприйнятніша для покупця”.

Однією з варіацій цієї тактики є обмеження покупця в часі шляхом повідомлення йому інформації про плановане чи неплановане закриття крамниці: $M u$ зараз закриваємося; Мене викликають на склад; Я змушений іти на іншу точку; Я перепрошую, мушу йти на іншу точку, то Ви берете иее? (з усного мовлення). У такий спосіб продавець чинить тиск на потенційного покупця, змушуючи його прийняти необдумане рішення;

\footnotetext{
${ }^{13}$ Р. Ч а лдин и, указ. источ., с. 222.
} 
- тактика виявлення негативних емоцій (нетерпіння, роздратування), дистанціювання, відмови від комунікативного контакту, напр.: Ви собі як хочете; Idimb, idimb, походіть ще (з усного мовлення)!; Не подобається - не купляйте!; Увесь товар на вітрині — дивиться самі!; Усі иүіни на вітрині - дивіться самі!; Вибирайте самі!14 і под.;

- тактика корегування поведінки покупця, оцінюваної негативно. За результатами здійсненого О. Харченко експерименту, до негативно оцінюваних реплік продавців належать ті, що стосуються регулювання поведінки покупця ${ }^{15}$. У межах цієї тактики виокремлюємо поради (напр., Не женіться за дешевим / дешевизною!) та “осмикування” і заборони (напр., Не хаміть мені!; Не заступайте людям вітрину!; Відійдіть, Ви заважаєте іншим роздивлятися товари!; Не заступайте прохід!; Не підходьте близько до вітрини!; Не займайте чергу, у нас скоро обід!; Не залапуйте руками товар, воно ж біле!; Не чіпайте руками продукиію!; Не навалюйтеся на прилавок!; Не підганяйте мене! і под.

Хоча продавці виявляють більшу активність під час комунікації з потенційними покупцями, що зумовлено характером соціальної ролі, регулятивні тактики використовують не тільки вони: покупці так само маніпулюють продавцями. Розглянемо комунікативні тактики, найчастіше застосовувані покупцями. Їхнє використання зумовлене прагненням покупця гармонізувати стосунки з продавцем, щоб отримувати правдиву інформацію про якість товару і його функційні характеристики, а також домогтися максимально можливої знижки на товар.

Серед регулятивних комунікативних тактик, використовуваних продавцем, домінантною є тактика підвищення значимості співрозмовника, що виявляється у позитивному оцінюванні товару, виставленого на продаж, рідше - приміщення торгівлі або самого продавця, а також у виявленні прихильного ставлення до нього, зокрема вираженні радості від спілкування / знайомства, співпраці та ін., напр.: Ваш сир найкращий. Скільки перепробувала, але у Вас зовсім інша якість!; У Вас завжди все свіженьке!; Добре, щзо на Вас натрапила!; А в окулярах Ви така інтелігентна!; Ви завжди порадите щзось добре!; У вас так гарно / затишно!; А який ремонт Ви зробили! (з усного мовлення).

Доволі поширеною в ситуаціях торгівлі є тактика позитивного самопрезентування покупця, що полягає в його позиціонуванні як постійного клієнта продавця. До цієї тактики покупці вдаються здебільшого на етапі торгування, щоб знизити ціну на обраний товар: Пане, я ж у Вас постійно все купую!; Та я Ваш постійний клієнт. Я до Вас щосуботи більше десяти років ходжу!; Тільки у Вас і купую!; Повірте, тільки до Вас ходжу!. Характерним прийомом, використовуваним під час реалізування цієї тактики, є виклад інформації про себе у формі третьої особи, що створює ефект об'єктивності й виглядає менш нав' язливо, порівн.: То, як? Зробите гарну знижку свосму постійному кліснmy? — “Зробите мені гарну знижку?”, Уступите трохи своєму найкращому / оптовому (розм.) покупцю? - “Уступите мені трохи?”. Як і продавці, покупці для неформалізації інтеракції зі своїм комунікативним партнером теж удаються до жартів та гумору, але більшість таких висловлювань є респонсивними.

Під час торгування покупці послуговуються також комунікативною тактикою самоприниження. Ї̈ суть полягає в демонструванні чи підкресленні свого невисокого соціального статусу, похилого віку, низької платоспромож-

${ }^{14}$ Е. В. Харченко, Модели речевого поведения в профессиональном общении, Челябинск 2003, с. 151, 147-148.

${ }^{15}$ Там же, с. 147. 
ності або належності до низькозабезпечених верств населення, напр.: Дядьку, та ми студенти, давайте за 20!; Панунцю, звідки в мене такі гроші?; Може, уступите, мені, пане? Живу на одну пенсію [...]; Продайте трошки дешевще старій бабиі!; Та я бідна пенсіонерка, продайте трошки таньше! (діал.); Та спустіть хоч троха (діал.) (з усного мовлення).

Під час торгування покупці апелюють до моральних якостей продавця, не тільки вдаючись до згаданої тактики самоприниження, напр.: (покупець хоче знизити ціну на одяг для немовляти) Давайте за 200 і хай маленьке здорове зносить? Такою пропозицією покупець ставить продавця в незручне становище: відповідаючи „НІ!”, продавець показує, що він не хоче, щоб дитина була здоровою й гарно носила одяг.

Покупці під час спілкування з продавцями використовують не лише конструктивні комунікативні тактики: популярною є тактика негативного оцінювання товару, застосовувана покупцями здебільшого на етапі торгування. Ïї суть полягає у вказуванні на певні недоліки товару, який покупець вирішив придбати, щоб знизити ціну на нього, напр.: Не знаю, чи буду брати. Тут строчка нерівна; Бачите, а тут тудзика немає!, Та [...] ие стара колекиія [...]; Пані, гляньте, а тут нитки торочаться!; Та це завіз ще 2015 року! (з усного мовлення). Описувана комунікативна тактика часто супроводжується демонстрацією вагань, приховуванням бажання здійснити покупки. У більшості випадків така комунікативна поведінка покупців не викликає негативної реакції продавців. Продавці йдуть на поступки та знижують ціну. Комунікативну ж тактику залякування чи погроз покупці використовують рідко - лише в разі виникнення конфліктної ситуації, пов'язаної з порушенням прав споживача, продажем неякісної продукції чи шахрайством, зухвалою поведінкою продавця.

Оцінюючи поведінку комунікантів у ситуаціях торгівлі, можна цілком погодитися з О. Харченко щодо домінування в них міжособистісного неофіційного спілкування над рольовим офіційним: „як професіонали, так і клієнти хочуть від співрозмовника особистісного ставлення до себе"16.

Отже, учасники неопосередкованої торгівлі використовують конструктивні та деструктивні регулятивні комунікативні тактики. При цьому продавці виявляють більшу активність у їхньому застосуванні, ніж покупці. Серед конструктивних тактик виокремлюємо тактику підвищення значимості співрозмовника, тактику позитивного самопозиціонування й тактику солідаризації. Деструктивними тактиками, використовуваними продавцями, уважаємо тактики докору, негативного оцінювання співрозмовника, залякування, вияву негативних емоцій, дистанціювання, відмови від контакту й корегування поведінки покупця. На етапі торгування покупці вдаються до використання тактики самоприниження й тактики негативного оцінювання пропонованого товару.

Високий рівень конкуренції в умовах ринкової економіки спричинює домінування в ситуаціях торгівлі конструктивних комунікативних тактик, що гармонізують спілкування та активізують продажі. Перспективним напрямом дослідження $\epsilon$ вивчення конфліктних комунікативних ситуацій, які найчастіше виникають під час неопосередкованої торгівлі, а також дослідження комунікативної поведінки продавців і покупців у крос-культурному вимірі.

${ }^{16}$ Е. В. Харченко, указ. источ., с.166. 


\section{Список використаної літератури}

Дімаров А., Сільські історії, Київ 1987.

Зленко И. П., Коммуникативное поведение франиузского продавиа, [в:] „Русское и французское коммуникативное поведение”, сб. науч. тр., научн. ред.: И. А Стернин, Р. А. Ермакова, Воронеж 2002, вып. 1, с. 16-19.

Кешеля Д., Осінь великих небес, або прирічанські характери, Ужгород 2006.

Космеда Т. A., Ego i Alter Ego Tapaca Шевченка в комунікативному просторі щооенникового дискурсу, Дрогобич 2012.

Сліпецька В., Засоби вираження негативних емочій під час сварки в украйнській, російській й англійській лінгвокультурах (на матеріалі творів I. Нечуя-Левицького, М. Гоголя, Ч. Діккенса), [w:] „Studia Ukrainica Posnaniensia”, 2018, Vol. VI, c. 159-165.

Стивенсон Ч., Некоторые прагматические аспекты значения, [в:] „Новое в зарубежной лингвистике", сб. науч. тр., гл. ред. Е. В. Падучева, Москва 1985, вып. XVI, c. $129-154$.

Таджибова Р. Р., Коммуникативно-прагматические особенности речевого этикета в различных лингвокультурах (на материале английского и лезгинского языков), [в:] „Вопросы когнитивной лингвистики”, 2013, вып. 2 (035), с. 151-157.

Харченко Е. В., Модели речевого поведения в профессиональном общении, Челябинск 2003.

Чалдини Р., Психология влияния, Санкт-Петербург 2002.

Шкіцька І. Ю., Маніпулятивні тактики позитиву: лінгвістичний аспект, Київ 2012.

\section{Spysok wykorystanoi literatury [References]}

Dimarov A., Silski istorii [Rural stories], Kyiv 1987.

Zlenko I. P., Kommunikativnoe povedenie frantsuzskogo prodavtsa [Communicative behavior of a French seller], [v:] ,Russkoe i frantsuzskoe kommunikativnoe povedenie”, sb. nauch. tr., nauchn. red.: I. A Sternin, R. A. Ermakova, Voronezh 2002, vyp. 1, s. 16-19.

Keshelia D., Osin velykykh nebes, abo pryrichanski kharaktery [Autumn of great heavens, or Pryrichany tempers], Uzhhorod 2006.

Kosmeda T. A., Ego i Alter Ego Tarasa Shevchenka v komunikatyvnomu prostori shchodennykovoho dyskursu [Ego and Alter Ego of Taras Shevchenko in the communicative space of the diary discourse], Drohobych 2012.

Slipetska V., Zasoby vyrazhennia nehatyvnykh emotsii pid chas svarky v ukrainskii, rosiiskii $y$ anhliiskii linhvokulturakh (na materiali tvoriv I. Nechuia-Levytskoho, M. Hoholia, Ch. Dikkensa) [Means of expression of negative emotions during quarrel in Ukrainian, Russian and English linguo-cultures (based on the works written by I. Nechui-Levytskyi, M. Hohol, Ch. Dickens)], [v:] „Studia Ukrainica Posnaniensia”, 2018, Vol. VI, s. 159165.

Stivenson Ch., Nekotorye pragmaticheskie aspekty znacheniya [Some pragmatic aspects of meaning], [v:] „Novoe v zarubezhnoj lingvistike”, sb. nauch. tr., gl. red. E. V. Paducheva, Moskva 1985, vyp. XVI, s. 129-154.

Tadzhibova R. R., Kommunikativno-pragmaticheskie osobennosti rechevogo ehtiketa $v$ razlichnyh lingvokul'turah (na materiale anglijskogo $i$ lezginskogo yazykov) [Communicative-pragmatic features of speech etiquette in various linguo-cultures (based on the materials of English and Lezgian languages)], [v:] „Voprosy kognitivnoj lingvistiki”, 2013, vyp. 2 (035), s. 151-157.

Kharchenko E. V., Modeli rechevogo povedeniya v professional'nom obshhenii [Models of verbal behavior in professional communication], Chelyabinsk 2003.

Chaldini R., Psikhologiya vliyaniya [Psychology of influence], Sankt-Peterburg 2002.

Shkitska I. Yu., Manipuliatyvni taktyky pozytyvu: linhvistychnyi aspekt [Manipulative positive tactics: linguistic aspect], Kyiv 2012. 